\title{
Influence of Perceived Supervisor Support on Organization Performance at Kakamega County Government, Kenya
}

\author{
Robert Mutisya Nzuki \\ Masters of Arts in Public Administration and Management, \\ School of Business and Economics, Mount Kenya University, Kenya \\ Appolonius Shitiabai Kembu, PhD \\ School of Business and Economics, Mount Kenya University, Kenya
}

\begin{abstract}
With the approach of managing performance, Employee responsibility has risen as a current authoritative idea as of late. The general objective was to establish the Influence of Perceived Supervisor Support on organization performance at Kakamega county government. The study was anchored in the Resource based view (RBV). The study hypothesized that there is a relationship between Perceived Supervisor Support and organization performance. A descriptive research design was applied. The target population was 332 employees of all degrees of the board and supervisory unit. Purposive examining was utilized to concentrate on specific qualities of a populace that are of enthusiasm under examination. A pilot test was directed on 10 employees to gauge the unwavering quality of the instruments. Data was examined utilizing Statistical Package for Statistical Scientists (SPSS) programming. To test unwavering quality and legitimacy, a pilot study was directed and Cronbach's coefficient alpha was utilized to set up consistency. A relapse model was utilized to show the connection between factors. The after effects of the exploration were introduced utilizing recurrence, figures and diagrams. The findings of the study, there is a positive relationship between Supervisor Support and organization performance. In Conclusion, that high quality perceived manager aid which includes supervisor encouraging on desirable overall performance. The study recommendation is that Kakamega County can enhance its organization performance by improving its policies regarding supervisor-subordinate staff relationship
\end{abstract}

Key Terms: Perceived supervisor support, engagement, employee commitment

\section{INTRODUCTION}

In the present corporate world, laborers 'desires go past the least remuneration and have changed the consideration of managers to perceiving the genuine idea of employee duty rehearses. Employee investment and employee-authoritative Perceived Supervisor Support are vital 
Nzuki, R. M., \& Kembu, A. S. (2020). Influence of Perceived Supervisor Support on Organization Performance at Kakamega County Government, Kenva. Archives of Business Research, 8(5). 191-200.

hierarchical needs as organizations face rivalry, rivals and imaginative people, and others, particularly arising out of a worldwide downturn to accomplish. (Baley et al., 2016; Aniha, 2014).

In correlation, barely any investigations have distinguished solid ties between programs started by supervisors and associations that upgrade employee inspiration and proficiency. Every association that exists has various highlights and conditions that make it difficult to make arrangements that can be promptly grasped by associations (Bandura and Lyons, 2014). Truth be told, dedicated laborers are required to have a trustful and top notch relationship with their chief (Saks, 2006; Karatepe, 2011). These submitted laborers, furthermore, execute their obligations all the more productively and go an additional mile in adapting to the issues of the organization and addressing the necessities of the customer.

Engagement through Perceived Supervisor Support and work fulfillment are known to be synonymous ideas; be that as it may, it can't for a fulfilled employee to fundamentally be a decent employee. (Musgrove et al., 2014). Numerous researchers in their investigations insist on the connection between hierarchical achievement and employee commitment, through Perceived Supervisor Support; for instance, Albdour and Altarawneh (2014). It is significant for arrangement creators and expository and useful specialists to concentrate on the proof base to make important enhancements in Perceived Supervisor Support practice, work fulfillment and employee mentorship and training. A really committed employee contributes enthusiasm and duty to their activity, which is legitimately associated with a positive authoritative network and additional activity, new thoughts and enhancements that help organizations flourish. As of late, because of a powerless monetary recuperation and unpredictable financial conditions, numerous organizations have decreased their selecting strategies, making the Commitment through Perceived Supervisor Support of laborers substantially more significant. Thinking about these issue it is imperative to consider the way of life, the board and different variables that influence employee Perceived Supervisor Support. The estimation of employee Perceived Supervisor Support is obvious while analyzing the inconsistencies in progress between workgroups with high and low paces of employee commitment. Gallup (2013) noticed that the work environment support plan is away from of the impact of employee duty on the primary concern.

\section{PROBLEM STATEMENT}

The emergence of devolved Governments in Kenya has experienced dramatic changes with major functions being decentralized. With the increase in demand for quality and timely services, an increase in population and scarce resources, counties have been forced to recruit the best and meet their obligations to the people they serve. Employee responsibility is one of the present issues in human assets the executives that numerous associations are confronting. Thus, employees realize that chiefs are liable for assessing their performance and see administrator support as a sign of authoritative help (Rhoades and Eisenberger, 2002). Employees see their bosses as specialists chipping away at the sake of the organization. (Baran et al., 2012).

Despite counties being the second largest employer in the country, the counties have to justify the numbers through better service delivery and customer satisfaction. According to performance management framework for county governments (2017), The counties has also been rocked with a series of employment of unqualified supervisory staff, promotion based on cronyism in addition they are yet to determine the influence of worker engagement in context of supervisory support in 
their organizations. There is anyway absence of any review by Gallup in enterprises in creating nations and in Africa, to be exact. An investigation by Devi (2009) found that pay and advantages are not remain solitary viable drivers of employee commitment. He reasoned that corporate culture adds to employee responsibility. His examination was anyway directed in the created world. The investigation subsequently planned for crossing over the current information holes in Perceived Supervisor Support on Optimizing Organizational Performance at Kakamega county government.

\section{Objective of the study}

This study sought to analyse influence of Perceived Supervisor Support on organization performance at Kakamega County Government.

\section{Value of the Research}

The current study intended to provide insights into knowledge about firm Perceived Supervisor Support on organization performance. The study will contribute towards filling the gap in the body of knowledge in the practices and operations of county governments in Kenya. The study intends to establish a link between Perceived Supervisor Support on organization performance, namely customer satisfaction and target achievement. This should not only ensure that the public who put their hope on county Governments for service delivery continue to reap the benefits.

\section{LITERATURE REVIEW}

\section{Theoretical Foundation of the research}

The RBV school of thought explains the importance of unique resources owned by an organization in achieving competitive advantage (Baumol, Litan \& Schramm, 2012). These resources take different forms including total assets expressed in monetary terms, experience of key human resources and the overall personnel adequacy. Other measures include networks among other variables (Bhide, 2013).

\section{Empirical Literature Review}

\section{Perceived Supervisor Support on organization performance}

Right now, bolster alludes to the degree to which administrators esteem their employees' work and care about their prosperity (Liaw, Chi and Chuang, 2010). Thus, employees realize that chiefs are liable for assessing their performance and see administrator support as a sign of authoritative help (Rhoades and Eisenberger, 2010). Employees see their bosses as specialists chipping away at sake of the organization. (Baran et al., 2012). Supervisory help is viewed as increasingly proximal to the laborers of the organization as expected hierarchical help (Eisenberger et al., 2010). An assortment of great work environment and occupation results are normal (Dysvik et al., 2014). Past discoveries show that quick administrators have a vital task to carry out in giving working environment sees on work conditions (Perrey et al., 2010; Rosen et al., 2011, for example, affecting inner adjustment to corporate approaches and systems (Puah et al., 2014). The help from line directors shifts with the necessity for help (Maertz et al., 2007). Nonetheless, the consistency of the trade course of action among managers and laborers relies fundamentally upon the certainty that laborers have in their bosses. (Dirks and Ferrin, 2002).

Also, laborers with a lower level of apparent business help are bound to direct withdrawal exercises that may unfavorably affect the prosperity of organizations, other staff and shoppers 
Nzuki, R. M., \& Kembu, A. S. (2020). Influence of Perceived Supervisor Support on Organization Performance at Kakamega County Government, Kenva. Archives of Business Research, 8(5). 191-200.

(Liao et al., 2010; Menguc et al., 2013). Right now, the guideline of social cooperation proposes that more noteworthy help from chiefs will empower laborers to turn out to be increasingly committed and to respond the association, for instance by urging their bosses to achieve their hierarchical objectives. Oppositely to that, as laborers get less help from their bosses, they won't bring full exertion into work (Dysvik et al., 2014). Accordingly, administrators have once in a while been accounted for to delay the effective execution of HR approaches (Purcell et al., 2009). Past work concentrated on the rule of social association (Shoe et al., 2009) has demonstrated that expected managers advance great authoritative proficiency and unfavorable turnover impacts, which is one of the antagonistic freak practices (Eisenberger et al., 2010; Kuvaas and Dysivk, 2010).

\section{Conceptual Frame Work}

The conceptual model figure 1 presents a schematic picture of the researchers presumed perception of the existing relationship between the variables. The model suggest relationship between perceived supervisors' support as the independent variable and organization performance as the dependent variable that may be influenced by perceived supervisors support.

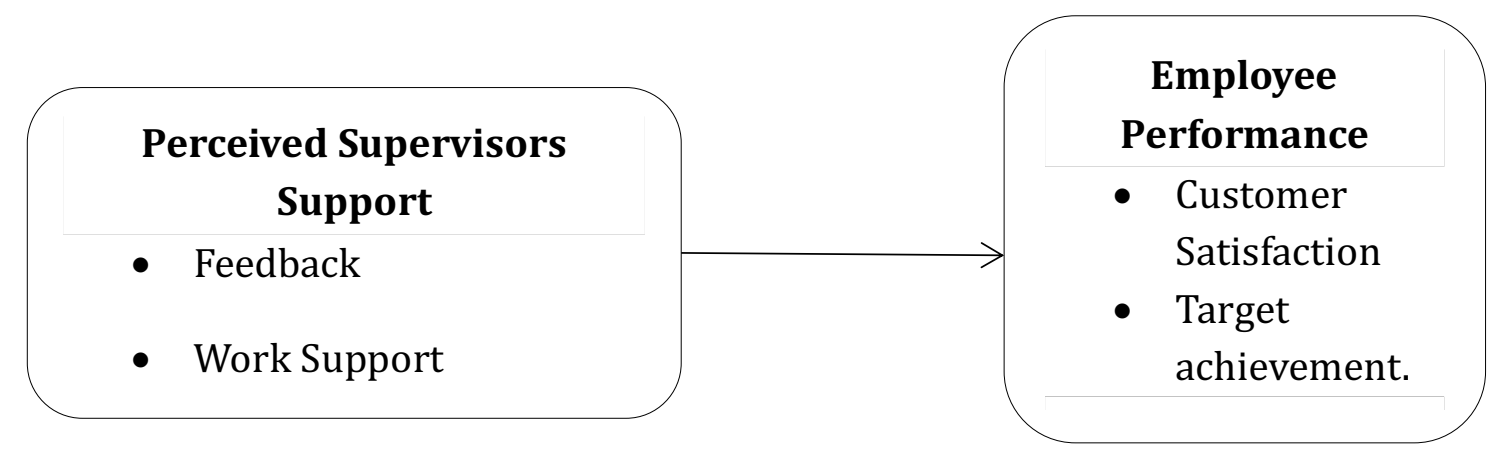

Fig 1. A Conceptual Model showing perceived supervisors support and employee performance. Source Researchers (2020)

The relationship indicated on figure 1 was envisaged to exist in organizations, but the application of different perceived supervisor support tend to influence employee performance. Perceived supervisor support include feedback and work support is perceived to influence employee performance.

\section{Research Design}

\section{METHODOLOGY}

The researcher used descriptive research design. It ensures nothing is manipulated and it describes the correlation within Variables. It provides information about real occurring situations and not experiments. As indicated by Zikmund, (2010), an expressive research configuration incorporates a procedure of gathering data which includes watching and portraying the conduct of a subject without impacting it in any capacity to address questions concerning the ebb and flow status of the subjects under examination and that it utilizes a pre-arranged structure for investigation. 


\section{Population of the study}

An examination populace is commonly an enormous assortment of people or articles that is the fundamental focal point of a logical question. Employees from Kakamega County formed the target group, management and supervisory cadre from different sub-counties 332 employees.

\section{Sample Population}

As indicated by Mugenda and Mugenda (2003), examining implies the assortment of a given number of things from a specific populace as illustrative of that populace. Populace examining is the way toward taking a subset of subjects that is illustrative of the whole populace. Mugenda depicts $30 \%$ as reasonable portrayal.

\section{Data collection}

The researcher used Questionnaires which were distributed door to door with the aid of the research assistants and the respondents given a length of 1 week thereafter collected, compiled and analyzed the statistics. The researchers sought authority from the National Council for Science, Technology and Innovation (NACOSTI) to collect data.

\section{Test of Validity and Reliability}

Content validation was also done by dividing the instrument into several sections. Each section was checked carefully checked to ensure that it conveys the necessary message and attracts the relevant feedback, as per the tested specific themes of the research objectives and research question.

To ensure reliability of the research instrument used in this study, a pilot study was conducted on 10 respondents who were not included in the main survey. To establish reliability results, the study tested for internal consistency using Cronbach Alpha. A threshold of 0.7 was adopted. The results indicate that perceived supervisor support and organization performance had Cronbach Alpha value above 0.7 which indicates that the data was reliable. This is consistent with Cronbach (1951).

Table 1: Reliability Test Results

\begin{tabular}{|c|c|c|c|}
\hline Scale & Cronbach's Alpha & Number of Items & Comment \\
\hline Perceived Supervisor Support & 0.816 & 7 & Reliable \\
\hline Organizational Performance & 0.782 & 5 & Reliable \\
\hline
\end{tabular}

Source: Field Data (2020)

\section{Data Analysis and Interpretation}

Simple linear regression analysis was used to establish the nature and magnitude of the relationship between variables; and to test hypothesized relationship. The coefficient $\mathbf{r}$ indicates the strength and direction of linear relationship between variables of the study. The relationship is strong where $\mathbf{r}=0.5$ and above, moderately strong when $\mathbf{r}$ is between 0.3 and 0.49 , weak when $\mathbf{r}$ is below 0.29 , and a correlation of 0 indicates no relationship.

\section{Response Rate}

A total of 202 questionnaires were administered to the Chief Officers, Directors, Administrators and head of departments at sub-county and ward levels in Kakamega County. Out of the number, 
Nzuki, R. M., \& Kembu, A. S. (2020). Influence of Perceived Supervisor Support on Organization Performance at Kakamega County Government, Kenva. Archives of Business Research, 8(5). 191-200.

115 questionnaires were properly filled giving a response rate of $57 \%$. The response rate of $57 \%$ is satisfactory based on the argument by Kombo and Tromp (2010) which indicated that for a survey study, a response rate above $60 \%$ is satisfactory.

\section{Demographic Characteristics}

The respondent's demographic characteristics including the respondent's age, highest level of academic qualification, working experience in the county and their category was established and presented in Table 2.

Table 2: Demographic Characteristics

\begin{tabular}{|c|c|c|c|}
\hline Demographic Characteristics & Category & Frequency & Percent \\
\hline \multirow{4}{*}{ Age } & Below 25 & 20 & 17.4 \\
\cline { 2 - 4 } & $25-35$ & 32 & 27.8 \\
\cline { 2 - 4 } & $36-45$ & 39 & 33.9 \\
\cline { 2 - 4 } & Above 45 & 24 & 20.9 \\
\hline \multirow{4}{*}{ Education } & Masters & 23 & 20 \\
\cline { 2 - 4 } & Undergraduate & 40 & 34.8 \\
\cline { 2 - 4 } & College & 52 & 45.2 \\
\hline \multirow{4}{*}{ Experience } & Less Than 1 Year & 37 & 32.2 \\
\cline { 2 - 4 } & Between 1 - 5 Years & 36 & 31.3 \\
\cline { 2 - 4 } & Between 6 - 10 Years & 18 & 15.7 \\
\cline { 2 - 4 } & Above 10 Years & 24 & 20.9 \\
\hline
\end{tabular}

Source: Field Data (2020)

The findings in Table 3 indicate that of the 115 respondents, 33.9\% of them were aged between 36 and 45 years, $20.9 \%$ were above 45 years of age while $45.2 \%$ were aged below 36 . On average, it can be argued that the majority of employees in Kakamega county are aged above 36 years. The results also established that majority of the respondents, $45.2 \%$, had college level of education as their highest, $34.8 \%$ of them had an undergraduate while $20 \%$ had masters. The results imply that majority employees in Kakamega County in the category of Chief Officers, Directors, Administrators and head of departments at sub-county and ward levels in Kakamega County have an undergraduate degree and above.

The results also revealed that majority of the respondents, 32.2\%, had a work experience below a year at the time of the study, $31.3 \%$ on the other hand had a work experience between 1 and 5 years while only $36.6 \%$ of the respondents had worked for a period more than 5 years. The findings imply that majority of the employees in top management position in Kakamega county had less than 5 years' work experience which can be attributed to changing political regimes.

\section{Descriptive statistics}

\section{Descriptive Findings of Perceived Supervisor Support}

The respondents rated five-point Likert scale questions on perceived supervisor support and the findings are indicated in Table 6. 
Table 3: Descriptive Findings of Perceived Supervisor Support

\begin{tabular}{|c|c|c|}
\hline Statement & Mean & $\begin{array}{c}\text { Standard } \\
\text { Deviation }\end{array}$ \\
\hline Boss supports on great performance & 4.30 & 0.89 \\
\hline Boss approaches subordinates with deference & 4.19 & 0.96 \\
\hline $\begin{array}{c}\text { Director keeps employees all around educated about what is } \\
\text { happening in the association }\end{array}$ & 4.10 & 0.99 \\
\hline Administrator empowers employee vocation advancement & 3.99 & 1.00 \\
\hline Administrator perceives the potential among employees & 3.94 & 1.02 \\
\hline Positive criticism on performance of employees by & 3.88 & 1.06 \\
\hline administrator with no inclination & 4.10 & 0.98 \\
\hline Manager is strong in taking care of business & $\mathbf{4 . 0 7}$ & $\mathbf{0 . 9 9}$ \\
\hline
\end{tabular}

Source: Field Data (2020)

The outcomes in Table 6 demonstrate that the respondents concurred that chief energizes on great performance $(\mathrm{M}=4.30)$, manager approaches subordinates with deference $(\mathrm{M}=4.19)$, administrator keeps employees very much educated about what is happening in the association (M $=4.10)$ just as support employee profession improvement $(\mathrm{M}=3.99)$. The respondents likewise concurred that chief perceives the potential among employees $(M=3.94)$, there is certain criticism on the performance of employees by manager with no predisposition $(M=3.88)$ and the director is steady in taking care of business $(\mathrm{M}=4.10)$.

Overall, the respondents agreed on statements on perceived supervisor support (Average Mean = 4.07). The results also showed varied opinions as shown by a standard deviation of 0.99 .

\section{Descriptive Findings of Organization Performance}

The respondents rated five-point Likert scale questions on Organization Performance and the findings are indicated in Table 4.

Table 4: Descriptive Findings of Organization Peryes formance

\begin{tabular}{|c|c|c|}
\hline Statement & Mean & $\begin{array}{c}\text { Standard } \\
\text { Deviation }\end{array}$ \\
\hline $\begin{array}{c}\text { Administration conveyance is according to client desire } \\
\text { Nature of administration keeps clients steadfast and thus rehashed } \\
\text { visits happen }\end{array}$ & 3.90 & 0.99 \\
\hline $\begin{array}{c}\text { Association minutely thinks about the client criticism and } \\
\text { recommendations }\end{array}$ & 3.83 & 0.99 \\
\hline Pledge to improve the nature of administrations routinely & 3.89 & 1.21 \\
\hline Employees are prepared in their particular utilitarian territories & 3.73 & 1.04 \\
\hline Average & $\mathbf{3 . 7 4}$ & $\mathbf{1 . 0 9}$ \\
\hline
\end{tabular}

Source: Field Data (2020)

The respondents concurred that administration conveyance is according to client desire $(\mathrm{M}=3.90)$, nature of administration keeps clients steadfast and consequently rehashed visits occur $(\mathrm{M}=3.83)$, there is pledge to improve the nature of administrations consistently $(M=3.89)$ and that 
Nzuki, R. M., \& Kembu, A. S. (2020). Influence of Perceived Supervisor Support on Organization Performance at Kakamega County Government, Kenva. Archives of Business Research, 8(5). 191-200.

employees are prepared in their individual useful territories $(\mathrm{M}=3.73)$. The respondents anyway neither concurred nor differ that the association minutely thinks about the client criticism and recommendations $(\mathrm{M}=3.37)$.

Table 5: Influence of perceived supervisor support on Organization Performance

\begin{tabular}{|c|c|c|c|c|c|c|c|}
\hline \multicolumn{8}{|c|}{ Model summary } \\
\hline \multicolumn{2}{|l|}{$\mathbf{R}$} & R Square & \multicolumn{2}{|c|}{ Adjusted R Square } & \multicolumn{3}{|c|}{ Std. Error of the Estimate } \\
\hline \multirow[t]{2}{*}{.618} & \multicolumn{2}{|r|}{0.382} & \multicolumn{2}{|l|}{0.366} & \multicolumn{3}{|c|}{0.61825} \\
\hline & \multicolumn{7}{|c|}{ ANOVA } \\
\hline & $\begin{array}{c}\text { Sum } \\
\text { of Squares }\end{array}$ & df & \multicolumn{2}{|c|}{ Mean Square } & \multicolumn{2}{|l|}{$\mathbf{F}$} & Sig. \\
\hline Regression & 26.273 & 3 & 8.758 & & \multicolumn{2}{|l|}{22.911} & .000 \\
\hline Residual & 42.428 & 111 & \multicolumn{2}{|l|}{0.382} & & & \\
\hline \multirow[t]{4}{*}{ Total } & 68.701 & 114 & & & & & \\
\hline & & \multicolumn{6}{|c|}{ Coefficients a } \\
\hline & & \multicolumn{2}{|c|}{$\begin{array}{c}\text { Unstandardized } \\
\text { Coefficients }\end{array}$} & \multicolumn{4}{|c|}{ Standardized Coefficients } \\
\hline & & $\mathbf{B}$ & Std. Error & \multicolumn{2}{|c|}{ Beta } & $\mathbf{t}$ & Sig. \\
\hline \multicolumn{2}{|c|}{ (Constant) } & 1.081 & 0.353 & & & 3.067 & 0.003 \\
\hline \multicolumn{2}{|c|}{ Perceived Supervisor Support } & 0.403 & 0.083 & & 33 & 4.872 & 0.000 \\
\hline \multicolumn{8}{|c|}{ Dependent Variable: Organization Performance } \\
\hline
\end{tabular}

Source: Field Data (2020)

a. Predictors: (Constant), Perceived Supervisor Support

b. Dependent Variable: Organization Performance

The model summary results in Table 5 indicate that the F statistic value of 22.911 is significant (Pvalue $<0.05$ ). This implies that the regression model linking perceived supervisor support, to organization performance was fit and can predict the outcome.

As indicated in Table 5, holding other factors constant that is perceived supervisor support, organization performance is 1.081 which is positive.

The results showed that perceived supervisor support has a positive and significant effect on organization performance $(\beta=0.403$; P-value $<0.05)$. This implies that a unit increase in perceived supervisor support leads to a significant increase in organization performance by 0.2403 units. The findings are consistent with Dysvik et al. (2014) who established that supervisory support predicts a positive effect of work outcomes.

\section{Conclusion}

\section{CONCLUSION AND RECOMMENDATIONS}

Another conclusion is that high quality perceived manager aid which include supervisor encouraging on desirable overall performance, treating subordinates with respect, maintaining personnel nicely informed about what goes on inside the company, encouraging employee 
profession improvement and recognizing the capability amongst employees results in a substantial boom in business enterprise overall performance.

\section{Recommendation}

Another recommendation is that Kakamega County can enhance its organization performance by improving its policies regarding supervisor-subordinate staff relationship. This can be done by the supervisor encouraging on good performance, treating subordinates with respect.

\section{References}

Albdour, A.A. what's more, Altarawneh, I.I. (2014) Employee responsibility and authoritative duty; proof from Jordan. General Journal of Business, 19, 192-212

Bailey, A. An., Albassami, F., and Al-Meshal, S. (2016). The occupations of representative work satisfaction and various leveled obligation in within exhibiting worker bank. Journal of Bank Advertising, 34(6), 821-840.

Baumol W., Litan R., and Schramm C. (2012). Extraordinary private business enterprise, awful free organization, and the economic matters of development and thriving. New safe haven, ct: Yale University Press.

Bandura, R. P., \&Lyons, P. R. (2014). The art and science of job satisfaction: Much of it comes

down to decent management practice. Human Resource Management International Digest, 22(7), 32-35.

doi:10.1108/HRMID-10-2014-014

Bhide, A. (2013). Self-Efficacy: in reference book of human conduct. ramachaudran, V.S VOL. 4, , 71-81

Devi, V, R., (2009). Representative duty is a two-way street, human asset the executives global condensation, 17 (2) 3 -4 .

Dirks, K. T., \& Ferrin, D. L. (2002). Trust in leadership: Meta-AnalyticWndings and implications for research and practice. Journal of Applied Psychology, 87, 611-628

Dysvik, A., Kuvaas, B., and Buch, R. (2014). Seen getting ready force and work effort: the coordinating activity of evident director support. European Journal of Work and Hierarchical Psychology,

Eisenberger, R., Stinglhamber, F., Vandenberghe, C., Sucharski, I.L. besides, rhoades, l. (2010), "Saw director support: duties to saw various leveled help and representative upkeep, Journal of Applied Brain Research, 87, 565-573

Gallup, C. (2013). The state of the overall workplace: a general examination of worker responsibility and thriving. omaha, ne: gallup. recuperated from http://www.gallup.com/strategicconsulting

Liaw, Y.- J., Chi, N.- W., and Chuang, A. (2010). Breaking down the instruments interfacing transformational activity, representative customer course and organization execution: Journal of Business and Brain Research,

Liao, Y., Hong, P. and Rao, S. (2010), “Supply management, supply flexibility, and performance

outcomes: an empirical investigation of manufacturing firms", Journal of Supply Chain Management, Vol. 46 No. 3, pp. 6-22.

Maertz, C. P., Griffeth, R. W., Campbell, N. S., and Allen, D. G. (2007). The effects of clear legitimate assistance and saw supervisor help on worker turnover. Journal of Authoritative Conduct, 28(8), 1059-1075

Menguc,B.,Auh,S.,Fisher,M.andHaddad,A.(2013),"To be engaged or not to be engaged:the antecedents and consequences of service employee engagement",Journal of Business Research,Vol.66,pp.2163-2170.

Mugenda, O. M. what's more, Mugenda, A. G. (2003). Investigate procedures: quantitative and emotional methodologies. Nairobi: African place for innovation considers.

Rhoades, L., and Eisenberger, R. (2002). Seen definitive assistance: a review of the composition. Journal of Applied Brain Research, 87(4), 698-714.

Perry, S. J., Witt, L. A., Penney, L. M., and Atwater, L. (2010). The downside of goal focused authority: The activity of character in subordinate exhaustion. Journal of Applied Brain Research. 
Nzuki, R. M., \& Kembu, A. S. (2020). Influence of Perceived Supervisor Support on Organization Performance at Kakamega County Government, Kenva. Archives of Business Research, 8(5). 191-200.

Purcell J, Kinnie N, Swart J, Rayton B, Hutchinson S (2009), People Management and Performance, London: Routledge.

Saks, A. M. (2006). Antecedents and consequences of employee engagement. Journal of Managerial Psychology, 21, 600-619. doi:10.1108/02683940610690169.

Shore, L. M., William, H., Bommer, W. H., Rao, A. N. and Seo, J. (2009). Social and economic exchange in the employeeorganization relationship: the moderating role of reciprocation wariness. Journal of Managerial Psychology, 24(8), 701-721.

Karatepe, Osman M. 2011. Procedural justice, work engagement, and job outcomes: Evidence from place countryregion Nigeria. Journal of Hospitality Marketing and Management 20 (8): 855-78.

http://dx.doi.org/10.1080/19368623.2011.577688

Musgrove, C.., Ellinger, A.., \& Ellinger, A. (2014) Examining the influence of strategic profit emphases on employee engagement and service climate. Journal of workplace learning, 26(3/4) 152-171.

Zikmund-Fisher B, Fagerlin A, Ubel P (2010): A demonstration of "less can be more" in risk graphics. Med Decis Making. 2010, 30 (6): 661-671. 10.1177/0272989X10364244. 